\title{
A TANÁRI MESTERKÉPZÉSI SZAK(OK)* INDÍTÁSÁNAK TAPASZTALATAI AZ AKKREDITÁCIÓ OLDALÁRÓL
}

\section{BAZSA GYÖRGY}

\author{
a MAB elnöke \\ bazsa@unideb.hu
}

Az elöadás ${ }^{1}$ a MAB akkreditációs tevékenységének tapasztalatai alapján áttekintést nyújt a felsöoktatás átalakulási folyamatairól, kiemelten a kompetenciaalapú képzés jelenlegi helyzetéröl, szakmai megértettségéröl és elfogadottságáról.

1999-ben Magyarország is aláírta Bolognában azt a ma már oktatástörténelminek nevezhető Nyilatkozatot, amelyik - többek között - a több- (elöször kettő, majd utóbb három) ciklusú lineáris képzési rendszer európai elterjesztését célozta meg. Hazai viszonylatban ez azt is jelentette, hogy megszünik a párhuzamos duális föiskolai-egyetemi képzési struktúra, s mind a föiskolák, mind az egyetemek egyazon képzési formára, szerkezetre állnak át. Először a kormányzat, majd jogelvi okok miatt az Országgyülés úgy döntött, hogy 2006-tól már csak az új rendszerben indulhat képzés a felsőoktatásban. Ez alól csak néhány ún. professzionális szakma kapott (ért el) felmentést: jogászok, orvosok, fogorvosok, állatorvosok, gyógyszerészek, építészek, ahol a képzés - lényegében változatlan formában s tartalommal osztatlan mesterképzés címen folytatódott tovább.

Az oktatáspolitikai döntés a tanárképzés radikális átalakítását is elöírta: egységes, kétciklusú, két szakképzettséget tartalmazó, mesterszinten megszerezhető diplomát adó tanárképzés lesz a közoktatás 5-12. osztályai számára - jelentős felfogásbeli, tartalmi változásokkal! Ismeretalapú helyett kompetencia alapú, kimenet vezérelt tanárképzést kíván a magyar közoktatás - szólt röviden a vezérfonal. Ezzel együtt is joggal mondható: paradigmaváltás következett be. Az egy külön kérdés, s ma sem elhanyagolható probléma, hogy kik mondták ezt el kiknek és hányan értették meg (és fogadták el) ennek lényegét a magyar tanárképzésben?

„Az ideális persze kétségkívül az lett volna, hogy lett volna egy átfogó koncepció, amit aztán valamennyi képzési területen végig tudunk vezetni. ... Teljesen egyetértek tehát azzal, hogy valóban egy új pedagogikumra van szükség. Ugyanakkor ezeknek az alapvető reformoknak a megvalósulásához látni kellene, hogy mik

\footnotetext{
* A felkérésben érkezett címben megadott „szakok” helyett hivatalosan tanári mesterképzési „szak” van.

${ }^{1}$ Az előadás a Tanárképzők Szövetségének rendezvényén hangzott el. Győr, 2009. január 31.
} 
lesznek azok a formai keretek, amikben ez megvalósulhat. Az erről szóló vitáknak konszenzusra kellene jutniuk, de ha ez nem sikerül, akkor is jogszabályt kellene alkotni, és akkor lenne mire felkészülnünk." (Hunyady György magánközlése, 2005)

A korábban mind föiskolai, mind egyetemi szinten lineáris tanárképzés

- $\quad$ egyrészt két ciklusra bomlott (a képzés így e tekintetben nem egységes),

- ahol az alapképzésben nem tanárszakra, hanem egy (a leendő egyik szakképzettségnek megfelelö) diszciplináris szakra jelentkezik a fiatal,

- majd ebben az alapképzési szakaszban elég hamar el kell döntenie, hogy tanár kíván-e lenni, és akkor teljesítenie kell a másik szakképzettséghez 50, valamint pedagógia-pszichológiai tárgyakból 10 kreditet,

- az alapképzés végén (nem tanári jellegü) záróvizsgát tesz a szakjának megfelelő diszciplinából (de nincs átfogó számonkérés/összegzés a másikból),

- jelentkezik (bármelyik erre jogosult intézményben) az egységes „tanári mesterszakra",

- ahol kiegészíti a két diszciplinában eddig szerzett ismereteit (az eddigi aránytalanságot részben kompenzáló mértékben), megszerzi a tanári mesterséghez elöírt 40 kreditnyi pedagógiai-pszichológiai-gyakorló tanítási (,pp”) ismereteket és készségeket, új elemként

- az 5. félévben külső gyakorlóhelyen (mentor mellett, de lényegében önálló) tanári feladatokat lát el,

- egységes tanári záróvizsgát tesz, aminek fontos eleme a jelölt által készített portfólió, de az új felfogásban nem ad számot a jelölt diszciplináris ismereteiröl,

- $\quad$ s végül mesterszintủ tanári oklevelet kap, amely megnevezi a két szakképzettséget is.

\section{A szaklétesítés}

Az egységes tanári mesterszak alapdokumentuma a képzési és kimeneti követelmények (KKK). A Bologna-rendszer bevezetésének előkészítése hazánkban két, időben elkülönült fázisban történt - elöször az alapszakok rendszere és KKK-i alakultak ki, majd néhány évvel később jelentek (és jelennek meg még ma is) a mesterszakoké. A tanári mesterszak $K K K$-nek elkészítése még tovább osztódott:

- 2006-ban megjelent a „koncepció” és a 40 kreditnyi pedagógiai és pszichológiai tárgyakat lefedő meglehetősen hosszú rész, majd

- az MRK pedagógusképzési bizottsága 2006/2007-ben, kilenc hónap alatt kidolgozta 83 szakképzettséghez ,a tantárgy-pedagógiát, a szakmódszertant is magába foglaló szakterületi ismeretek"-et.

A MAB az első értékeléskor ezek zömét a benyújtott formában nem támogatta, tartalmi korrekciót, átdolgozást kért, és ebben érdemben közremüködött. A „máso- 
dik fordulóban" - erős nyomás alatt - elfogadta, és az OKM 2007 nyarán honlapján (s majd rendeletben is) megjelentette. A 15/2006. (IV. 3.) OM rendelet 4. számú melléklete az tanári mesterszakon belül 83 szakképzettséget tartalmaz.

Egy oktatáspolitikus szerint a jelen helyzet:

a) a jelenlegi KKK-kban a tanulási eredmények, kompetenciák leírásai funkciótlanul, „díszként” fityegnek a tartalmi-procedurális szabályozó elemek mögött, több elemzés eredménye szerint szakon, tudományterületen és teljes rendszeren belüli inkoherenciákkal, ellentmondásokkal,

b) az EKKR-rel (Európai Képesítési Követelmények Rendszere) összevetésben a képzések szintezése egyenetlen, a 6. szint szinte hiányzik (az alapképzések az 5. szintre konvergálnak, a mesterképzések inkább a 7. szint felé),

c) a mesterképzések bemeneti feltételeinek kialakítása során a tartalmi elemek figyelembevétele dominál és nem a kimeneti kompetenciáké,

d) a tanulási eredmények és kompetencia leirások jelen állapotukban - és az $\mathrm{OKM}$, a MAB és az intézmények jelenlegi figyelem-orientációinak erőterében - képtelenek betölteni kimeneti szabályozó szerepüket. (Derényi András: A tanulási eredmény felőli megközelítés a felsőoktatás képzési rendszerének szabályozásában, Tanulási eredmények workshop, Budapest, 2007. szeptember 24.)

A KKK, mint müfaj természetesen nem köteles része a Bologna-rendszernek. De nem is magyar specifikum. Csak egy példa Angliából - röviden: „This programme specification (PS) is designed for prospective students, enrolled students, academic staff and potential employers. It provides a concise summary of the main features of the programme and the intended learning outcomes that a typical student might reasonable be expected to achieve and demonstrate if he/she takes full advantage of the learning outcomes and content of each module - can be found in the Definitive Module Document (DMD) and the module teaching plan (Module Guide)."

\section{A szakindítási beadványok}

A szakindítási beadványokhoz minden beadó és MAB szakértő számára alapdokumentum az OKM honlapján megtalálható (kis késéssel a közlönyben is megjelenö) képzési és kimeneti követelmények. Ezen túl a MAB útmutatót és részletes követelményeket tett közzé a beadványok egységes szerkezete és az összehangolt elbírálása érdekében. Külön tanári szakindítási útmutató készült, konkrét kívánalmakkal a pedagógai-pszichológia-gyakorlati képzési rész és külön a szakképzettségek számára (közismerten „A” lap és „B” lapok). Minden intézmény csak egy „A” lapot ad be a pedagógiai-pszichológiai-gyakorlati részről és a 11. félévről (amelyik az intézmény bármely szakképzettségéhez adekvát) - ezt szakértők értékelik, majd 
a Tanárképzési Bizottság (TkB) és a plénum alakítja ki és fogadja el a MAB szakértői véleményét.

Az intézmények tetszőleges számú, a szakképzettség diszciplináris ismereteire és kompetenciáira koncentráló „B” lapot adhatnak be, annak megfelelöen, hogy hány tanári szakképzettség oktatására kérnek akkreditációt. Ezeket szakértők értékelik, majd a képzési ági bizottságok (KÁB), s végül a kollégiumok és a tanárképzési bizottság javaslata alapján a plénum határoz.

A szakinditási beadványok meghatározó elemei

Elvi alap: (szigorú) megfelelés a KKK-nek

$\checkmark$ tanterv, tantárgyi programok, kredittáblázat, záróvizsga-terv, 11. félévi gyakorlat feltételei; (a MAB kiegészitésként azt kérte, hogy a vizsgarendben a 10. félév végén legyen 1-1 szaktárgyi zárószigorlat a rendezett, szintetizált tudás kialakításához és a két szakképzettség ismeret-szintjének közelítéséhez);

$\checkmark \quad$ az oktatási és kutatási háttérrel bíró oktatói gárda (az oktatói terhelés maximálása a „kis szakokon” nehéz helyzetet teremtett, ezt a MAB igyekszik rugalmasan kezelni);

$\checkmark \quad$ a szakmának megfelelő infrastruktúra, az $\mathrm{OH}$ által akkreditált elégséges kapacitás.

„Olvasva a különböző dokumentumokat, azt tapasztalom, hogy a tanulási eredmények alapú megközelítés nemhogy ezeket a változásokat nem éri el, de még a különböző jogszabályokban sem érvényesül következetesen, a szaklétesítési és szakindítási dokumentumokban pedig végképp csak formálisan jelenik meg. A kompetenciákat, mint szükséges díszletet beírják a szakindítás elejére és a tantárgyleírások elejére is, azonban mindennek semmilyen hatása nincs a szakok tervezetének szemléletére. Abban még inkább kételkedem, hogy a szakok oktatására mindennek jelentős hatása lenne." (Falus, 2007)

Ugyan mitől lenne - kérdezem én az említett előzmények után?

\section{A mostani helyzet kialakulása és jellemzése}

A mostani helyzet adatszerüen:

- Beérkezett 264 tanári szakindítási beadvány.

- Ebből 176 igen, 82 nem, 6 folyamatban (átlag).

- Felülvizsgálati Bizottság a MAB plénum „nem”-je után ,igen”-t mondott 5 esetben.

- Legtöbb kezdeményezett tanári szakképzettségre van valahol MAB támogatás, így indulhat. Kivételek: japán, kínai, ukrán, bolgártanár, dráma- és múzeumpedagógia, életvitel, ügyvitel tanár.

- 20 tanárképzést folytató intézménynek van több vagy még több, ám olykor kevesebb indítási joga. 
- Kedvezőtlen a „tanárképző főiskolák” első közismereti szakjainak támogatottsága. Náluk több a „második” tanári szakképzettség.

A kétciklusú tanári mesterképzés sínen van, ám a sín is göröngyös, a szerelvény is döcög - de megy. A paradigmaváltást a szféra többsége nem értette meg és nem tudta érvényesíteni sem a KKK-k, sem a szakindítási beadványok elkészítésében.

A pedagogikumnak a 111-es rendelet már jó elóéletet és biztos közös alapot jelentett, de a diszciplináris oldal szakmai hiányként, olykor veszteségként/vereségként élte meg: maga az új elnevezés, ami a diszciplinát nem tartalmazza, az eddigi egyciklusú, bár duális, de egységes rendszer átalakítása (megtörése) két ciklusra, a diszciplinák kreditvesztése (az azonos súlyú két szak helyett a „minor” szak kevesebb kreditje), a diszciplináris tanszékek elvesztették a tanári szakdolgozókat.

A tanári/nem tanári közös belépés előnyei ma még nem láthatók, inkább hátrányai érezhetők.

Mi jelent meg ebböl a MAB-ban?

- Előző plénum hagyatéka: őrizzük meg az egyetemi szintü tanárképzés színvonalát! Ez előre jelezte, hogy a föiskolák számára sok esetben nem könnyen teljesíthető szakmai követelményszint érvényesül. Létrehozta az Ftv. szerinti „homogén” (diszciplinamentes) Tanárképzési Bizottságot. Ezzel, mint kiderült, kódolta a kétféle felfogás (erős diszciplína vs. tanári mesterség) gyakori ütközését. (Lásd Pukánszky Béla előadását, Eger, 2008. április 26.)

- A jelen plénum konkrét esetek kapcsán érzékelte a felfogásbeli különbségeket, s azt is, hogy tantervekben a kompetenciaalapú képzési felfogás és kimeneti szabályozás mérsékelten érzékelhető, továbbra is erősebb az ismeretközpontúság. Ez a MAB-ban is tükröződött, ezért konszenzuskeresési közös fórumot szerveztünk, de ez nem vezetett lényegi eredményre. „Véleményem szerint a MAB-ban természetszerüleg tükröződik az a felfogásbeli és értelmezési sokszínűség, ami az új rendszerü tanárképzésről az egész magyar felsőoktatásban jól érzékelhetően megvan. A mi feladatunk viszont nemcsak a vita, hanem a döntés is, és ezért helyzetünk és felelösségünk karakteresebb, mint más (vita)fórumoké.” [2008. január 4. MAB belső egyeztetés a tanári beadványok akkreditációjáról.]

\section{Egységes tanárképzés! Egységes tanárképzés?}

A kérdés maga is ellentmondásokra utal. Érdemes összefoglalni az új rendszer egységes és eltérő elemeit.

Egységes elemek:

$\checkmark$ egységesen csak mesterszinten lehet tanári szakképesítést szerezni: egy tanári mesterszak van, de természetesen csak szakképzettség(ek)hez kötötten, mert e(zek) nélkül a tanári mesterszak üres fikció; 
$\checkmark$ egységes kell legyen a tanárjelölt felkészítése a (záhonyi) általános iskola 5. osztályától a (budapesti Apáczai Gyakorló Gimnázium) emelt szinten érettségiző osztályán át a (letenyei) szakközépiskola tanulói számára;

$\checkmark$ egységes képzési és kimeneti követelmények vannak minden szakképzettségre, függetlenül az előképzettségtől;

$\checkmark \quad$ egységesek a pedagógiai-pszchológiai-gyakorlati képzés moduljai (10+40 kredit +30 kredites gyakorló félév);

$\checkmark$ egységesen kell két szakmai zárószigorlatot tenni;

$\checkmark$ egységes (kellene legyen) a záróvizsga felfogása.

Nem egységes elemek:

- nem egységesen kötelező a két szakképzettség: ez csak a közismereti tanárképzés nagy részében (a kétciklusú nappali képzésben) kötelező, de számos más képzési változatban nem:

- a közismereti területen is szerezhető egy szakképzettség - a nappali tagozatos hallgató csak két szakiránnyal, a kiegészítő képzésben résztvevő levelező - nem tanári mesterszakra, továbbá föiskolai végzettségre épülően már egy szakiránnyal is kap mesterszintủ végzettséget és ezzel magasabb fizetési besorolást;

- a müvészeti és szakmai tanárképzésben általános az egy szakképzettség (de még ezen belül sincs egység: a müvésztanár lehet „egyszakos”, a testnevelő tanár nem);

- nem egységes a 83 szakképzettség súlya: vannak első és második, és vannak csak második szakképzettségek;

- nem egységes a két közismereti szakképzettség felkészülési aránya (kreditjeinek száma) az alap- + mesterképzésben, így a két szakképzettség szakmai megalapozottsága sem;

- nem egységes a két közismereti szakképzettség megalapozása: csak az egyikböl van záróvizsga alapszakon.

\section{Hogyan összegezhetünk?}

- Az új rendszer elindult, most fontos mérföldkőnél tart. Kérdés: hány jelentkezö lesz a 4.051 állami helyre?

- A kezdetektől meglévő, nem kibeszélt, nem megoldott feszültségeket a MAB sem tudta levezetni, s mivel csak a MAB van döntéskényszerben, döntéseiben ezek olykor felerösödnek és visszhangoznak.

- A MAB-ban erős az akadémiai szemlélet, az ismeretközpontúság, ez is okoz olykor feszültséget.

- Az intézményi érdekek gyakran felülírták az értékeket: a sok jól előkészített mellett jelentős számú megalapozatlan beadvány is született. 


\section{És hogyan tovább?}

- Átgondoltan fel kell készülni az intézményekben a tanári mesterszak oktatására.

- Tájékoztatni kell a közoktatást az új tanári mesterszakról.

- Folyamatosan gyüjteni és értékelni kell a tapasztalatokat, erényeket, hibákat!

\section{Irodalom}

Derényi András: A tanulási eredmény felöli megközelités a felsőoktatás képzési rendszerének szabályozásában. Tanulási eredmények workshop, Budapest, 2007. szeptember 24.

Falus Iván: A kompetencia-alapú képzés a gyakorlatban. Tanulási eredmények workshop, Budapest, 2007. szeptember 24.

Hunyady György magánközlés, 2005.

MAB belső egyeztetés a tanári beadványok akkreditációjáról, 2008. január 4.

Pukánszky Béla előadása, Eger, 2008. április 26. 